\title{
The ionic liquid 1-octyl-3-methylimidazolium (M80I) is an activator of the human estrogen receptor alpha
}

Alistair C. Leitch ${ }^{1}$, Anne F. Lakey ${ }^{1}$, William E. Hotham ${ }^{1}$, Loranne Agius ${ }^{1}$, George E.N. Kass ${ }^{2}$, Peter G. Blain ${ }^{1}$, Matthew C. Wright ${ }^{1, *}$

\footnotetext{
${ }^{1}$ Institute Cellular Medicine, Health Protection Research Unit, Level 4 Leech, Newcastle University, Newcastle Upon Tyne, United Kingdom NE24HH.

${ }^{2}$ European Food Safety Authority, Via Carlo Magno 1A, 43126 Parma, Italy.

${ }^{*}$ Corresponding author. Address: Institute Cellular Medicine, Level 4 Leech Building; Newcastle University, Framlington Place, Newcastle Upon Tyne, UK. M.C.Wright@ncl.ac.uk
}

Email addresses: A.C.Leitch@ncl.ac.uk (A. Leitch), Anne.Lakey@ncl.ac.uk (A. Lakey),

W.E.Hotham1@newcastle.ac.uk (W. Hotham), loranne.agius@ncl.ac.uk (L Aguis), ,

Georges.KASS@efsa.europa.eu (G Kass), peter.blain@newcastle.ac.uk (P. Blain)

M.C.Wright@ncl.ac.uk (M. Wright).

\author{
Abbreviations \\ AhR, aryl hydrocarbon receptor; ICl182780, also known as fulvestrant; E2, $17 \beta$ estradiol; EE, \\ ethinylestradiol; ER $\alpha$, estrogen receptor alpha, also known as NR3A1; ER $\beta$, estrogen receptor beta, \\ also known as ER3A2; M8OI, 1-octyl-3-methylimidazolium chloride, also known as C8min; PBC, \\ primary biliary cholangitis; PPAR $\alpha$, peroxisome proliferator activated receptor alpha; TFF1, trefoil \\ factor 1 .
}




\section{ABSTRACT}

Recent environmental sampling around a landfill site in the UK demonstrated that unidentified xenoestrogens were present at higher levels than control sites; that these xenoestrogens were capable of super-activating (resisting ligand-dependent antagonism) the murine variant 2 ER $\beta$ and that the ionic liquid 1-octyl-3-methylimidazolium chloride (M8OI) was present in some samples. To determine whether $\mathrm{M} 8 \mathrm{O}$ I was a contributor to the xenoestrogen pool in the soils, activation of human estrogen receptors by $\mathrm{M} 8 \mathrm{OI}$ was examined. $\mathrm{M} 8 \mathrm{OI}$ activated the human ER $\alpha$ in MCF7 cells in a dose-response manner. These effects were inhibited by the ER antagonist ICI182780; occurred in the absence of any metabolism of $\mathrm{M} 8 \mathrm{OI}$ and were confirmed on examination of ER-dependent induction of trefoil factor 1 mRNA in MCF7 cells. M8OI also super-activated the murine variant 2 $E R \beta$ in a murine hepatopancreatobiliary cell line. The human ER $\beta$ was not activated by $M 80$ I when expressed in HEK293 cells. These data demonstrate that M8OI is a xenoestrogen capable of activating the human $E R \alpha$ and super-activating the murine variant $2 E R \beta$.

\section{KEYWORDS}

C8Mim; ionic solvent; nuclear receptor; xenoestrogen; ER alpha; ER beta 


\section{Introduction}

Recent studies from this laboratory applied cell-based in vitro toxicity studies to screen for chemicals present in environmental samples such as soil and water. Using this approach, it was shown that for an urban area in the North East of the UK, chemicals activating the aryl hydrocarbon receptor (AhR) or peroxisome proliferator activated receptor alpha (PPAR $\alpha)$ - e.g. by polyaromatic hydrocarbons and surfactant pollutants respectively - were widely present in the soils naturally and/or through anthropomorphic activity. In contrast, chemicals that activated the human estrogen receptor alpha $(E R \alpha)$ were at higher levels in soils around a landfill site compared to control soils from the region $[1,2]$.

Two sampling sites down-wind of the landfill waste site also contained a chemical that was toxic to an hepatocyte progenitor cell line [2]. The soil extracts from these sites inhibited mitochondrial electron transport and induced apoptosis [2]. The identity of the chemical was determined to be the ionic liquid M8OI [2]. Ionic liquids are relatively recently developed solvents that are liquid at ambient temperatures yet also non-volatile. For this reason, ionic liquids have been proposed as a new class of "green solvents" [3].

Since the two sampling sites containing M8OI also showed high estrogenic (ER $\alpha$-activating) activity [2], we hypothesised that $\mathrm{M} 8 \mathrm{OI}$ is an activator of ERs and its presence in these two sampling sites may have contributed - in part - to the high estrogenic activity of extracts from these sampling sites.

There are 2 ER genes in man - ER $\alpha$ and estrogen receptor beta (ERß) [4]. In complementary work, we have recently shown that soil-derived unidentified chemical(s) are capable of "super-activating" a variant (v2) murine ERß in pancreatohepatobiliary cells, in that the receptor resists antagonism by the antagonist ICI182780 (whereas activation by $17 \beta$ estradiol [E2] remains readily antagonised [1]). The ability of $\mathrm{M} 8 \mathrm{OI}$ to activate the human ERß has therefore also been examined. 


\section{Materials and methods}

2.1. Materials and plasmids

M8OI was purchased from Sigma (Poole, UK). The (ERE) $)_{3}-\mathrm{pGL} 3$ promoter and pcDNA3.1-mERßv2 (encoding the mouse ER $\beta$ variant 2 transcript) construct was originally prepared and validated as previously described $[5,1]$. A pcDNA3.1 construct encoding a FLAG-tagged human ERß originally constructed by the Srinivas laboratory [6], was obtained via Adgene (plasmid \# 35562).

\subsection{Cell culture, transfection and dual luciferase assays}

The human breast cancer MCF7 cell line (obtained from Dr Katherine Rennie, Newcastle University), human embryonic kidney 293 cell line (HEK293, purchased from the European Collection of Cell Cultures [ECACC, Porton Down, UK]) and murine cholangiocyte 603B cell line (a gift from Dr Yedidya Saiman, Mount Sinai School of Medicine, New York) were all cultured in low glucose Dulbecco's Modified Eagles Medium (Sigma, Dorset, UK), supplemented with 10\% (v/v) foetal bovine serum (Sigma) and $80 \mathrm{U} / \mathrm{ml}$ of penicillin and streptomycin. The human $\mathrm{H} 69$ cholangiocyte cell line [7] was routinely expanded in 3:1 (v/v) ratio of DMEM and Nutrient F12 Ham's medium supplemented with $180 \mu \mathrm{M}$ adenine, $2 \mathrm{nM}$ triiodothyronine, $5.5 \mu \mathrm{M}$ epinephrine, $1 \mu \mathrm{M}$ hydrocortisone, $10 \% \mathrm{v} / \mathrm{v} \mathrm{FCS}, 1 \mathrm{x}$ Insulin/transferrin/selenium (Gibco) and 1 x Pen/Strep (Lonza). All cell lines were maintained in a humidified atmosphere at $37^{\circ} \mathrm{C}$ in $5 \% \mathrm{CO}_{2}$ in air. MCF7 cells constitutively expressing ER $\alpha$ [5] were transiently transfected with (ERE) 3 -pGL3promoter [5] and RL-TK (Promega, UK) - to control for transfection efficiency - at a ratio of 10:1 using Effectene reagent (Qiagen, Manchester, UK), according to the manufacturer's instructions. All other cell lines - cultured in 24-well plates - were transiently transfected with $0.25 \mu \mathrm{g}$ total DNA per well (pcDNA3.1 expression vector encoding the cDNAs for either the FLAG-tagged human ER $\beta$ or mER $\beta v 2$; the estrogen-responsive $(E R E)_{3}-$ 
pGL3promoter reporter gene luciferase construct [5] and RL-TK (Promega, UK) - to control for transfection efficiency - at a ratio of 6:6:1 using polyethylenimine (Sigma, Poole, UK) for the MCF7 and HEK293 cells and Effectene reagent (Qiagen, Manchester, UK), for the 603b cells according to the manufacturer's instructions. Twenty four hours after transfection, cells - where applicable were pre-treated with ER antagonists for 6 hrs before being treated with estrogens or potential xenoestrogens from 1000-fold concentrated stocks in in DMSO or PBS. Following treatment for 24 hours, Firefly and Renilla luciferase activities were determined using a Dual-Glo luciferase assay kit (Promega, UK) as previously described [5]. Since the mERßV2 exhibits near complete constitutive activity when expressed in 603B cells [1,8], cells transfected with the pcDNA3.1 construct encoding the $m E R \beta v 2$ were pre-treated with the ER antagonist ICI 182780 for 6 hrs followed by five wash steps with large volumes of sterile PBS to reduce the levels of antagonist. Cells were then treated with estrogens or potential xenoestrogens from 1000 -fold concentrated stocks in DMSO or PBS in the absence, and where indicated, in the presence of $\mathrm{ICl} 182780$.

Mouse hepatocytes were isolated via a two-step collagenase perfusion and hepatocyte isolations essentially as previously detailed [9]. Hepatocytes (typically > 90\% viable as determined by trypan blue exclusion [9]) were then cultured on collagen-coated 6 well plates in William's medium $E$ supplemented with $10 \%(\mathrm{v} / \mathrm{v}) \mathrm{FCS}, 80 \mathrm{u} / \mathrm{ml}$ penicillin, $80 \mu \mathrm{g} / \mathrm{ml}$ streptomycin, $10 \mathrm{nM}$ dexamethasone and $1 \mu \mathrm{g} / \mathrm{ml}$ insulin. Cells were cultured overnight in an humidified atmosphere at $37^{\circ} \mathrm{C}$ in $5 \% \mathrm{CO}_{2}$ in air. The medium was then aspirated and cells were washed in sterile PBS and subsequently cultured as above without the addition of FCS.

\subsection{Metabolism of $\mathrm{M} 8 \mathrm{OI}$.}

Culture medium was aspirated and the cells were washed 3 times with sterile PBS $(1.37 \mathrm{M} \mathrm{NaCl}, 27$ $\mathrm{mM} \mathrm{KCl}, 100 \mathrm{mM}$ phosphate $\mathrm{pH} 7.4$ ) prior to incubation with $\mathrm{M} 8 \mathrm{OI}$ in $0.10 \mathrm{M} \mathrm{NaCl}, 5.4 \mathrm{mM} \mathrm{KCl}$, 
$0.34 \mathrm{mM} \mathrm{Na}_{2} \mathrm{HPO}_{4} 12 \mathrm{H}_{2} \mathrm{O}, 0.44 \mathrm{mM} \mathrm{KH}_{2} \mathrm{PO}_{4}, 20 \mathrm{mM}$ glucose, $1 \mathrm{mM} \mathrm{CaCl}, 40 \mathrm{mM} \mathrm{NaHCO}, 4 \mathrm{mM}$

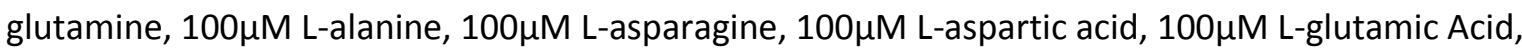
$100 \mu \mathrm{M}$ glycine, $100 \mu \mathrm{M}$ L-proline and $100 \mu \mathrm{M}$ L-serine ( $\mathrm{pH} 7.4$ when gassed with $5 \% \mathrm{CO}_{2}$ in air). As a control, M8OI was incubated identically in a cell-free culture vessel. At various time points, incubation medium was centrifuged to remove any cellular material and acidified with 0.1 volumes 1\% phosphoric acid. Acid soluble material analysed by HPLC using a Shimadzu LC-10AD liquid chromatograph using authentic M8OI as standard using a Diamonsil C18 $(4.6 \times 150 \mathrm{~mm}, 5 \mu \mathrm{m})$ column (Sigma) maintained at $50^{\circ} \mathrm{C}$ and a mobile phase flow rate of $1 \mathrm{~mL} / \mathrm{min}$. The mobile phase consisted of $A[0.1 \% \mathrm{w} / \mathrm{v}$ phosphoric acid (aq)] and B [acetonitrile] and sample constituents were separated using the following gradient conditions: $90 \%$ A : 10\% B changing to $10 \%$ A : $90 \%$ B from 0 - 15 mins; $10 \%$ A : $90 \%$ B between 15 and 35 mins; $10 \%$ A : 90\% B changing to $90 \%$ A : $10 \%$ B from 35 - 40 mins followed by a wash at $90 \%$ A : $10 \%$ B from $40-55$ mins. Elution was monitored at $211 \mathrm{~nm}$.

\subsection{TFF1 mRNA expression determined via qRT-PCR}

MCF7 cells were exposed to estrogens or other chemicals for 24 hours. The cells were then washed in ice-cooled PBS and total RNA was isolated using Trizol (Invitrogen, Paisley, UK) following the manufacturer's instructions. RNA was quantified by UV spectrophotometry and TFF1 mRNA and 18S rRNA levels were determined by qRT-PCR using the Applied Biosystem PowerUp SYBR Green master mix and StepONE RT-PCR system machine using primers and essentially as previously described [5].

\subsection{MTT assays.}

Thiazolyl blue tetrazolium bromide (MTT) reduction was used to screen for cell viability by replacing culture media with fresh media containing $0.5 \mathrm{mg} / \mathrm{ml} \mathrm{MTT}$ and incubating for between 2-4 hours. The medium was then replaced with an equal volume of isopropanol and after mixing, absorbance 
was determined at $570 \mathrm{~nm}$ (with background absorbance at $690 \mathrm{~nm}$ also determined and reading subtracted from reading at $570 \mathrm{~nm})$. Results are expressed as percentage absorbance relative to vehicle treated cells.

2.6. Statistical analyses.

For a study with 3 or more conditions with 1 independent variable, a one-way ANOVA followed by a Bonferroni post-hoc test was performed. For a study with 3 or more conditions with 2 independent variables, a two-way ANOVA followed by Bonferroni post-hoc test was performed. For testing the difference between 1 independent variable with one variation in treatment, the Student's T test was used. In all cases, significant difference ( 2 tailed) was judged at the $p<0.05$ level. 


\section{Results}

\subsection{M8OI activates the human ER $\alpha$}

To determine whether M8OI (for structure, see Fig. 1) is a human ER $\alpha$ activator, MCF7 cells transfected with an ER-responsive reporter construct were exposed to M8OI or known ER activators E2 (an endogenous estrogen) or ethinylestradiol (EE, a synthetic estrogen). Fig. 2a demonstrates that $\mathrm{M} 8 \mathrm{OI}$ activated the human $\mathrm{ER} \alpha$ in a dose-responsive manner with significant measurable activation over control occurring at concentrations of at least $25 \mu \mathrm{M}$. Figure $2 \mathrm{~A}$ also demonstrates that the ER antagonist ICI182780 [10] inhibited M8OI and E2 or EE reporter gene activity in cell extracts, supporting a role for the ER $\alpha$ in mediating the effects of $\mathrm{M} 8 \mathrm{O}$ on reporter gene induced expression. Figure $2 \mathrm{~b}$ and $2 \mathrm{c}$ indicate that there was no detectable metabolism of $\mathrm{M} 8 \mathrm{OI}$ over a 24 hour period - in contrast to a low level of disappearance in cultures of mouse hepatocytes suggesting that $\mathrm{M} 8 \mathrm{OI}$ itself rather than a metabolite was responsible for the activation of the ER $\alpha$ in MCF7 cells.

The human ER $\alpha$ transcriptional effects of $\mathrm{M} 8 \mathrm{OI}$ were further confirmed through quantitative RT-PCR analyses of trefoil factor 1 (TFF1) mRNA expression. Fig. 3a demonstrates a marked and significant dose-response increase in TFF1 expression in MCF7 cells exposed to M8OI, with a peak at $10 \mu \mathrm{M}$ and robust block in induction when cells were co-treated with $\mathrm{ICI} 182780$. The cause of the reduction in TFF1 transcription between 10 and $25 \mu \mathrm{M} \mathrm{M8OI} \mathrm{was} \mathrm{occasionally} \mathrm{also} \mathrm{observed} \mathrm{with} E R \alpha /(E R E)_{3}-$ pGL3promoter-dependent luciferase expression. Fig. 3b indicates that M8OI was toxic to MCF7 cells on the basis of significant reduced MTT activity at concentrations of $5 \mu \mathrm{M}$ or greater. The toxic effects of M8OI therefore likely ablated its estrogenic effect in MCF7 cells and underestimated its potency to activate the human ER $\alpha$. 


\section{2. $\mathrm{M} 8 \mathrm{OI}$ is a super-activator of the mouse $E R \beta$ variant 2 receptor.}

The mouse generates 2 ER $\beta$ proteins by alternative splicing, with variant 2 (orthologous to the human ER $\beta$ protein) lacking an in-frame exon in the coding region of variant 1 (resulting in a variant 2 protein lacking variant 1 amino acids 383-400 [1]). Figure 4a demonstrates, using a mouse hepatopancreatobiliary cell line, that $\mathrm{M} 8 \mathrm{OI}$ acts as a super-activator of the murine ER $\beta$ variant 2 receptor since $\mathrm{M} 8 \mathrm{OI}$ receptor activation was not blocked by the antagonist ICI182780 in contrast to when the receptor was activated by E2 or EE.

To our knowledge, a human cell line expressing transcriptionally functionally-detectable ER $\beta$ (in the absence of $\mathrm{ER} \alpha$ ) is not available. Therefore, to determine whether $\mathrm{M} 8 \mathrm{OI}$ is an activator of the human ER $\beta, H E K 293$ cells were transiently transfected with an expression construct encoding the human ER $\beta$ in order to generate cells expressing the receptor protein. Figure $4 b$ demonstrates that M8OI failed to activated the human ER $\beta$ in HEK293 cells. Similar results were also also observed when these studies were repeated in the human H69 cholangiocyte cell line (data not included).

\subsection{Discussion}

This study was conceived from a project seeking to identify potential environmental xenobiotic triggers for primary biliary cholangitis (PBC), an auto-immune chronic liver disease characterised by bile duct inflammation and destruction. PBC incidence is most common in post-menopausal women and is associated with genetic pre-dispositions $[11,12]$, however, it is thought that xenobiotic exposure(s) trigger the disease [13-16]. PBC is associated with a loss of tolerance to the lipoic acidconjugated regions of the mitochondrial branched chain $\alpha$ keto acid dehydrogenase complex and anti-mitochondrial antibodies in patient sera $[17,18]$. Thus, one potential trigger for PBC may be exposures to chemicals that structurally and chemically mimic lipoic acid, and may therefore be capable of enzymatic incorporated into PDC-E2 in place of lipoic acid $[17,18]$. However, an 
estrogenic activity may increase the likelihood of a sustained injury since estrogens at elevated levels are widely recognised to be hepatotoxic primarily through a cholesatic effect.

Since the environmental study identified $\mathrm{M} 8 \mathrm{O}$ in a region that also contained unidentified xenoestrogens at higher levels than control sample sites, we hypothesised that M8OI could be a component of the chemicals in the environmental samples activating the ERs. We demonstrate in this report that $\mathrm{M} 8 \mathrm{OI}$ is a xenoestrogen capable of activating the human ER $\alpha$ receptor. Although we demonstrate that $\mathrm{M} 8 \mathrm{O}$ is capable of super-activating the murine ER $\beta$ variant 2 protein, activation of any nature was not seen in the human orthologue ERB. Super-activation therefore has currently only been observed in murine cholangiocyte cells and may be specific to these cells or species. Alternatively, given that response element and ligands (agonists or antagonists) are independent modulators of ER conformation and that ligands modulate ER-cofactor interaction [19], it may be that both HEK293 and H69 cholangiocytes differ to $603 \mathrm{~b}$ cells in the presence of a co-factor permissive for super-activation.

Xenoestrogens are exogenous chemicals that mimic the activity of estrogens. A xenoestrogen may be a chemical that interacts with a variety of receptors mediating the biological effect of estrogens as hormones, although other mechanisms could have an estrogenic effect (e.g. by disrupting estrogen bioavailability). These data indicate that M8OI has the potential to act as a xenoestrogen in man through at least an interaction with the ER $\alpha$. In the context of the liver and PBC, this estrogenic activity - be it from $\mathrm{M} 8 \mathrm{OI}$ or to related imidazolium-based solvents - may be relevant to a xenobiotic-induced trigger for PBC. ER $\alpha$ is expressed in hepatocytes whereas both ER $\alpha$ and ER $\beta$ are expressed in cholangiocytes and expression is increased in cholestatic liver injury settings $[20,21]$. Estrogens have been proposed to regulate the expression of factors controlling proliferative (via $E R \alpha)$ or apoptotic (via $E R \beta$ ) responses of cholangiocytes $(20,21)$.

Thus, $\mathrm{M} 8 \mathrm{OI}$ - in addition to directly inhibiting liver cell oxidative phosphorylation in the mitochondria [2] and readily being metabolised to a carboxylic acid metabolite with structural 
similarity to lipoic acid by human hepatocytes [2] - may also be capable of disrupting normal bile duct homeostasis through interaction with the ER $\alpha$ in man.

\section{Acknowledgements}

This work was funded by the National Institute for Health Research Health Protection Research Unit (NIHR HPRU) in Chemical and Radiation Threats and Hazards in partnership with Public Health England (PHE) and the MRC (in the form of an ITTP studentship supporting A.C.L.). The work was also supported by the British Toxicology Society (vacation studentship to W.E.H). The views expressed are those of the author(s) and not necessarily those of the NHS, the NIHR, the Department of Health, Public Health England or the British Toxicology Society. 


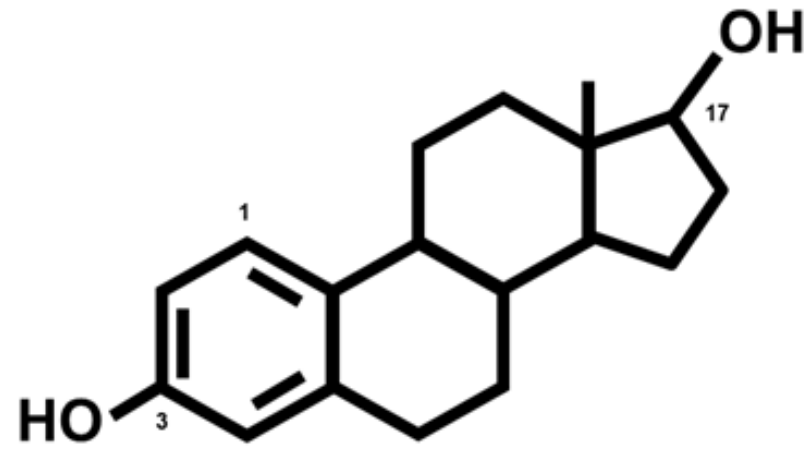

$17 \beta$ estradiol

(E2)

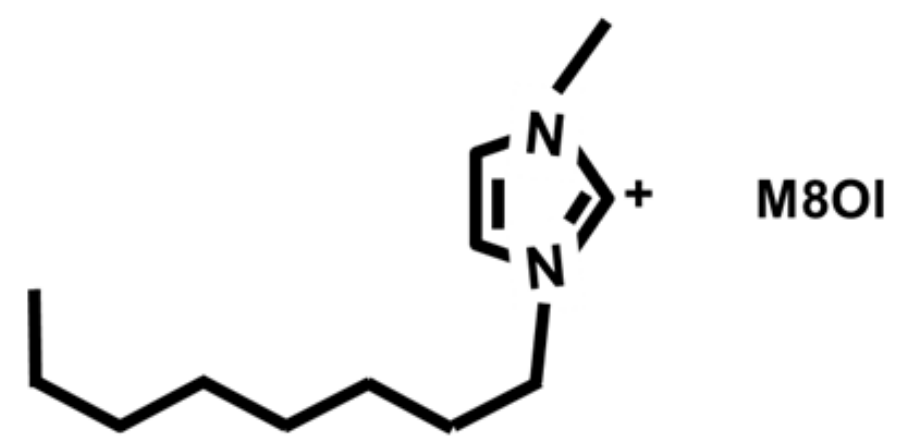

Fig. 1. Comparison of the chemical structures of $17 \beta$ estradiol and M8OI. 
A

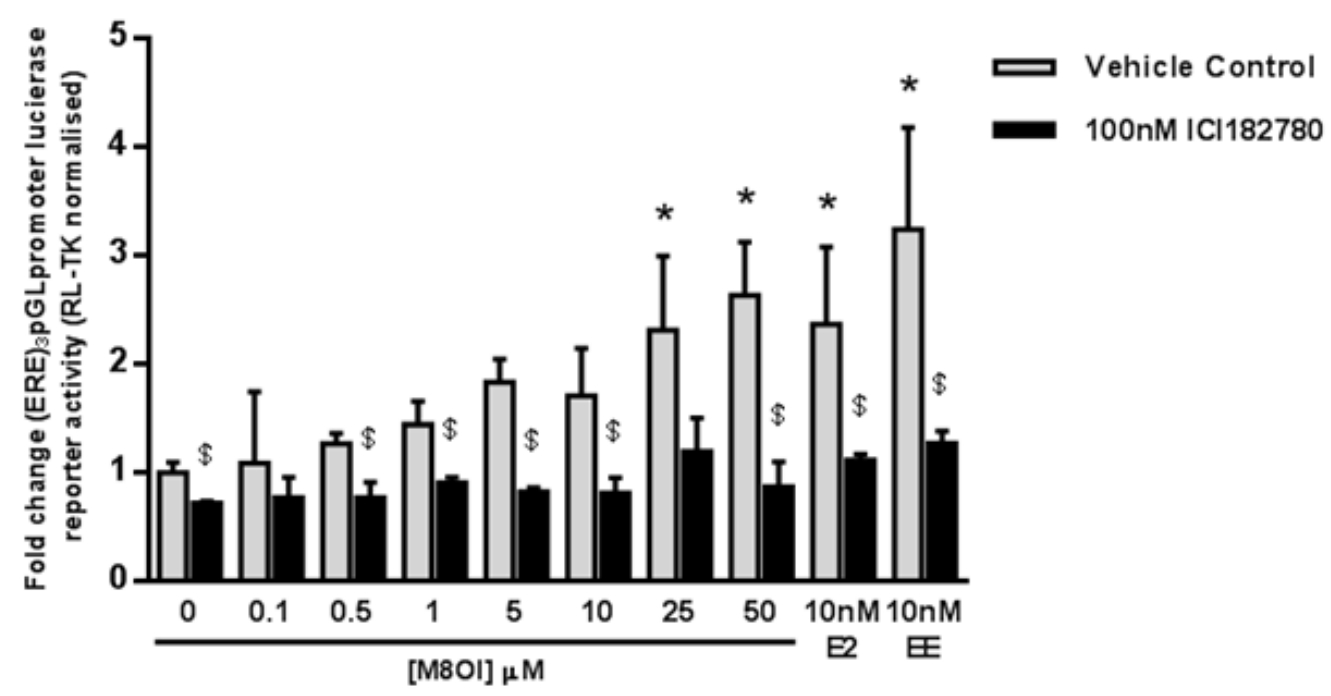

B

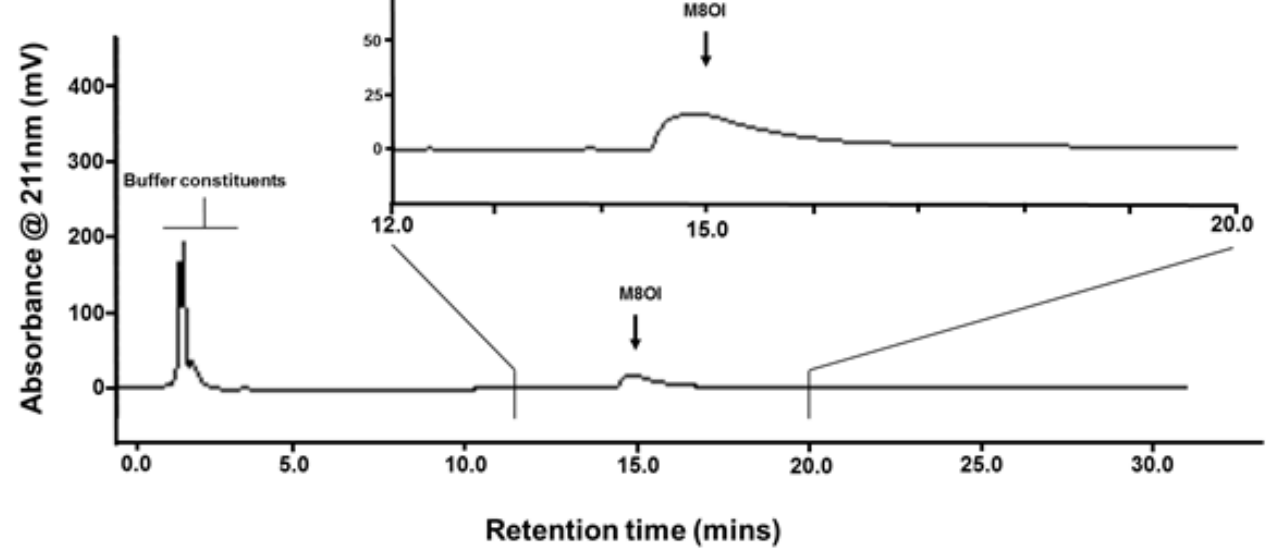

C

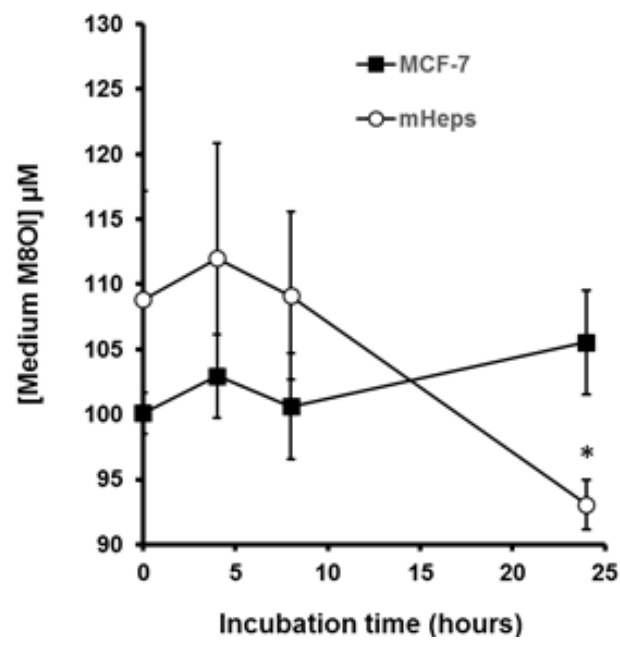


Fig. 2. M8OI activates the human ER $\alpha$ in MCF7 cells. A, luciferase reporter gene (ERE) $3^{-}$ pGL3promoter assay in MCF7 cells. Cells were transiently transfected as outlined in the methods

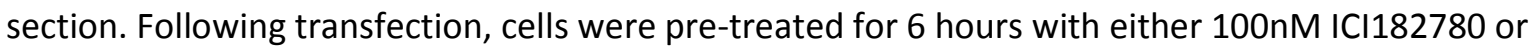
vehicle (DMSO, $0.1 \% \mathrm{v} / \mathrm{v})$. Cells were then treated with indicated compounds in continued presence of ICl182780 or vehicle for a further 24 hours prior to analysis. Data are the mean and SD of 3 separate determinations from the same experiment, typical of 3 separate experiments. ${ }^{*}$ Significantly different $(p<0.05)$ versus DMSO vehicle-treated $(0 \mu \mathrm{M})$ cells using two-way ANOVA followed by

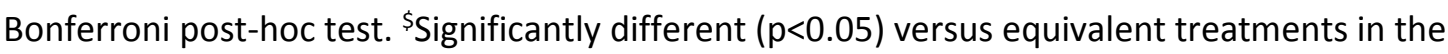
absence of ICI182780 using Student's t-test (two-tailed). B, Typical HPLC chromatogram of $100 \mu \mathrm{M}$ M8OI in STIM buffer. C, Disappearance of M8OI in MCF7 and mouse hepatocyte culure media. Cells were incubated with $100 \mu \mathrm{M}$ of M8OI in STIM buffer for 24 hours and samples taken over a 24 -hour period and analysed by HPLC as in B. Data are the mean and SD of 3 separate experiments. *Significantly different $(p<0.05)$ versus time zero using one-way ANOVA followed by a Bonferroni post-hoc test. 
A

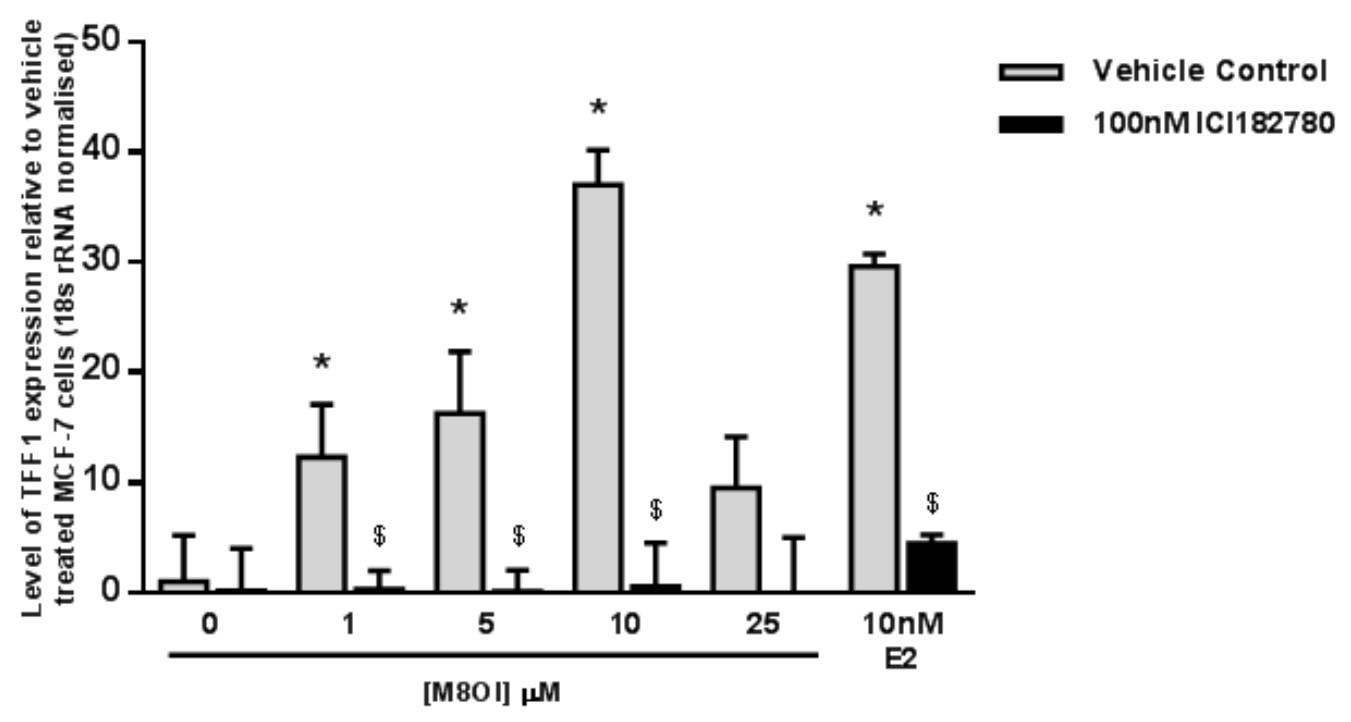

B

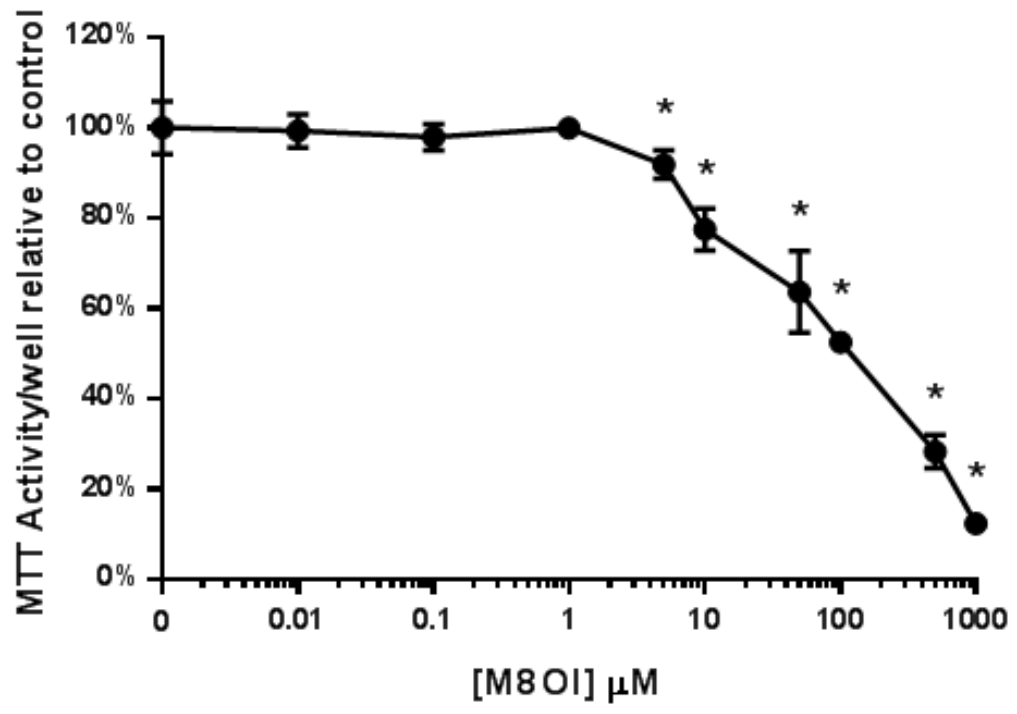

Fig. 3. M8OI induces expression of TFF1 mRNA in MCF7 cells. A, MCF7 cells were pre-treated with $100 \mathrm{nM} \mathrm{ICl} 182780$ or DMSO vehicle $(0.1 \% \mathrm{v} / \mathrm{v})$ as indicated for 6 hours followed by the treatment with the indicated compounds in the continued presence of ICI182780 or vehicle. After 24 hours, total RNA was extracted and TFF mRNA and 18S rRNA expression determined. TFF mRNA was normalised to $18 \mathrm{~S}$ rRNA expression and fold change expressed relative to control vehicle-treated cells. Data are the mean and SD of 3 separate experiments. ${ }^{*}$ Significantly different normalised TFF1 
expression $(p<0.05)$ versus $0 \mu \mathrm{M}$ (DMSO vehicle) treated cells using two-way ANOVA followed by Bonferroni post-hoc test. \$Significantly different $(p<0.05)$ versus equivalent treatments in the absence of ICI182780 using Student's t-test (two-tailed). B, MTT reduction in MCF7 cells following 24 hours incubation with the indicated concentration of M8OI. Results are expressed as the mean and SD of 3 separate determinations and are expressed as a percentage of $0.1 \%(\mathrm{v} / \mathrm{v})$ DMSO vehicle. *Significantly different $(\mathrm{p}<0.05)$ versus DMSO vehicle-treated $(0 \mu \mathrm{M})$ cells using one-way ANOVA followed by Bonferroni post-hoc test. 
A

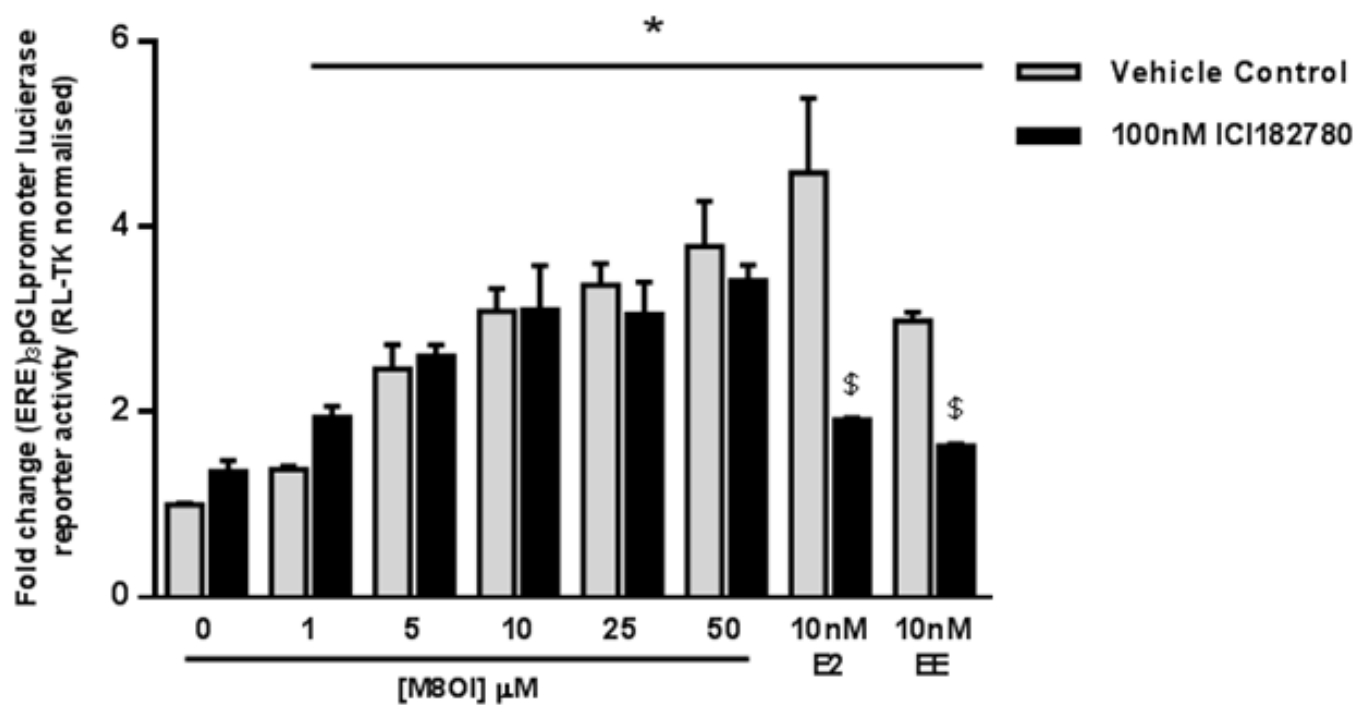

B

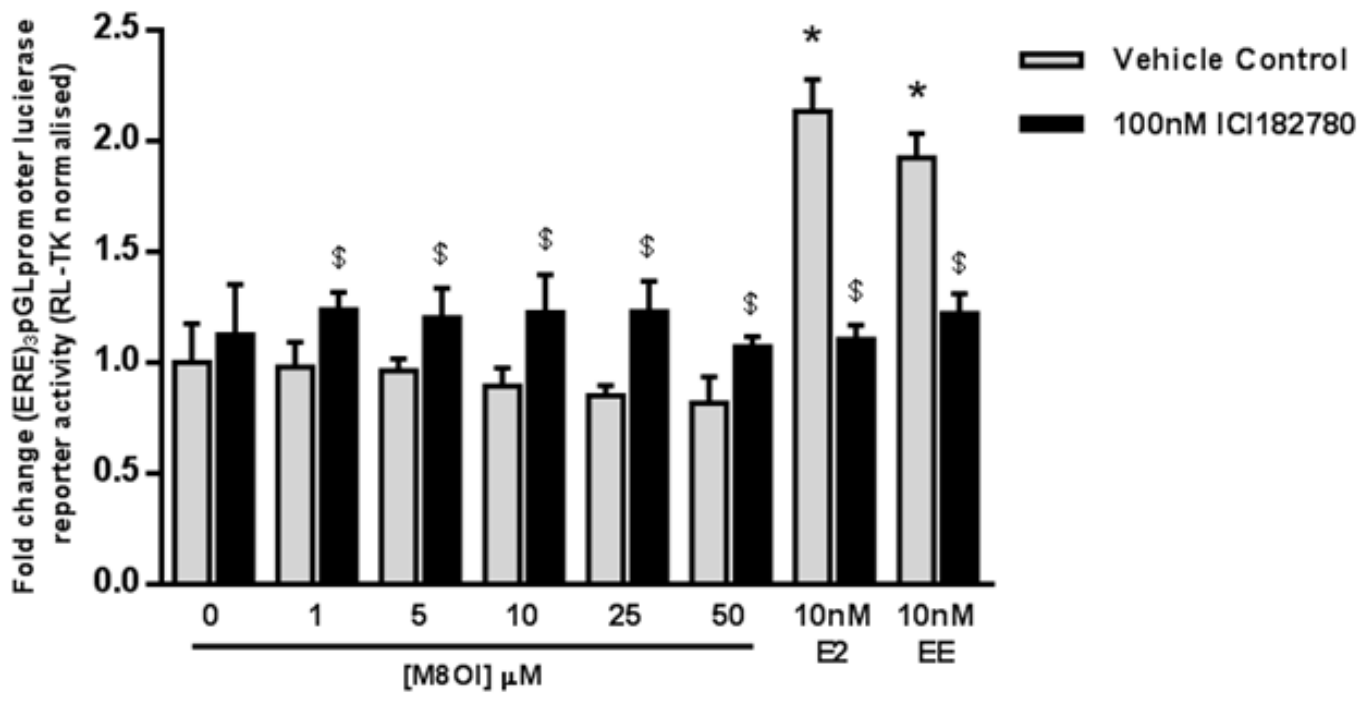

Fig. 4. M8OI is a super-activator of the mouse ER $\beta$ variant 2 but does not activate the human ER $\beta$.

A, luciferase reporter gene (ERE)3-pGL3promoter assay in 603B cells co-transfected with the expression construct encoding mERßv2. Cells were transiently transfected as outlined in the methods section. Following transfection, cells were pre-treated for 6 hours with 100nM ICI182780 to de-activate constitutively-active mERßv2. At time zero, cells were washed with PBS and treated with the indicated compounds for a further 24 hours prior to analysis. Data are the mean and SD of 3 separate determinations from the same experiment, typical of 3 separate experiments. "Significantly 
different $(p<0.05)$ versus DMSO vehicle-treated $(0 \mu \mathrm{M})$ cells using two-way ANOVA followed by Bonferroni post-hoc test. \$Significantly different $(p<0.05)$ versus equivalent treatments in the absence of ICI182780 using the Student's t-test (two-tailed). B, luciferase reporter gene (ERE)3pGL3promoter assay in HEK293 cells co-transfected with the expression construct encoding hER $\beta$. Cells were transiently transfected as outlined in the methods section. Following transfection, cells were pre-treated for 6 hours with $100 \mathrm{nM} \mathrm{ICI} 182780$ or vehicle (DMSO, $0.1 \% \mathrm{v} / \mathrm{v}$ ). Cells were then treated with indicated compounds in continued presence of ICI182780 or vehicle for a further 24 hours prior to analysis. Data are the mean and SD of 3 separate determinations from the same experiment, typical of 3 separate experiments. "Significantly different $(p<0.05)$ versus DMSO vehicletreated $(0 \mu \mathrm{M})$ cells using two-way ANOVA followed by Bonferroni post-hoc test. ${ }^{\$}$ Significantly different $(p<0.05)$ versus equivalent treatments in the absence of $\mathrm{ICl} 182780$ using Student's t-test (two-tailed).

\section{References}

1. S.K. Meyer, P.M. Probert, A.F. Lakey, L.I. Blake, A.C. Leitch, P.A. Jowsey, M.P. Cooke, P.G. Blain, M.C. Wright, Environmental xenoestrogens super-activate a variant murine ER beta in cholangiocytes. Toxicol. Sci. 156 (2017) 54-71.

2. P.M. Probert, A.C. Leitch, M.P. Dunn, S.K. Meyer, J.M. Palmer, T.M. Abdelghany, A.F. Lakey, M.P. Cooke, H. Talbot, C. Wills, W. McFarlane, L.I. Blake, A.K. Rosenmai, A. Oskarsson, R. Figueiredo, C. Wilson, G.E. Kass, D.E. Jones, P.G. Blain, M.C. Wright, Identification of a xenobiotic as a potential environmental trigger in primary biliary cholangitis. J. Hepatol. $2018 \mathrm{Jul} 10$ in press. pii: S01688278(18)32182-2. doi:10.1016/j.jhep.2018.06.027.

3. M.E. Heckenbach, F.N. Romero, M.D. Green, R.U. Halden, Meta-analysis of ionic liquid literature and toxicology. Chemosphere 150 (2016) 266-274. 
4. M. Bondesson, R. Hao, C.Y. Lin, C. Williams, J.Å. Gustafsson, Estrogen receptor signaling during vertebrate development. Biochim. Biophys. Acta 1849 (2015) 142-51.

5. A. Axon, F.E. May, L.E. Gaughan, F.M. Williams, P.G. Blain, M.C. Wright, Tartrazine and sunset yellow are xenoestrogens in a new screening assay to identify modulators of human oestrogen receptor transcriptional activity. Toxicology 298 (2012) 40-51.

6. G. Zhang, N. Yanamala, K.L. Lathrop, L. Zhang, J. Klein-Seetharaman, H. Srinivas H, Ligandindependent antiapoptotic function of estrogen receptor-beta in lung cancer cells. Mol. Endocrinol. 24 (2010) 1737-47.

7. S.A Grubman, R.D. Perrone, D.W. Lee, S.L. Murray, L.C. Rogers, L.I. Wolkoff, A.E. Mulberg, V. Cherington, D.M. Jefferson, Regulation of intracellular pH by immortalized human intrahepatic biliary epithelial cell lines. Am. J. Physiol. 266 (1994) G1060-70.

8. S.K. Meyer, P.M. Probert, A.F. Lakey, A.R. Axon, A.C. Leitch, F.M. Williams, P.A. Jowsey, P.G. Blain, G.E. Kass, M.C. Wright, Hepatic effects of tartrazine (E 102) after systemic exposure are independent of oestrogen receptor interactions in the mouse. Toxicol. Letts. 273 (2017) 55-68.

9. P.M. Probert, G.W. Chung, S.J. Cockell, L, Agius, P. Mosesso, S.A. White, F. Oakley F, C.D. Brown, M.C. Wright, Utility of B-13 progenitor-derived hepatocytes in hepatotoxicity and genotoxicity studies. Toxicol. Sci. 137 (2014) 350-70.

10. S.E. Wardell, J.R. Marks, D.P. McDonnell, D. P, The turnover of estrogen receptor a by the selective estrogen receptor degrader (SERD) fulvestrant is a saturable process that is not required for antagonist efficacy. Biochem. Pharmacol. 82(2011) 122-130.

11. P.T. Donaldson, A. Baragiotta, M.A. Heneghan, A. Floreani, C. Venturi, J.A. Underhill, D.E. Jones, O.F. James, M.F. Bassendine. HLA class II alleles, genotypes, haplotypes and amino acids in primary biliary cirrhosis: a large-scale study. Hepatology 44 (2006) 667-74. 
12. G.F. Mells, J.A. Floyd, K.I. Morley, H.J. Cordell, C.S. Franklin, S.Y. Shin, M.A. Heneghan, J.M. Neuberger, P.T. Donaldson, D.B. Day, S.J. Ducker, A.W. Muriithi, E.F. Wheater, C.J. Hammond, M.F. Dawwas; UK PBC Consortium, Wellcome Trust Case Control Consortium, D.E. Jones, L. Peltonen, G.J. Alexander, R.N. Sandford, C.A. Anderson. Genome-wide association study identifies 12 new susceptibility loci for primary biliary cirrhosis. Nat. Genet. 43 (2011) 329-32.

13. D.R. Triger. Primary biliary cirrhosis: an epidemiological study. Br Med J. 281 (1980) 772-5.

14. M.I. Prince, A. Chetwynd, P. Diggle, M. Jarner, J.V. Metcalf, O.F. James. The geographical distribution of primary biliary cirrhosis in a well-defined cohort. Hepatology 34 (2001) 1083-8.

15. A. Ala, C.M. Stanca, M. Bu-Ghanim, I. Ahmado, A.D. Branch, T.D. Schiano, J.A. Odin, N. Bach. Increased prevalence of primary biliary cirrhosis near Superfund toxic waste sites. Hepatology 43, (2006) 525-31.

16. M.I. Prince, S.J. Ducker, O.F. James. Case-control studies of risk factors for primary biliary cirrhosis in two United Kingdom populations. Gut 59 (2010) 508-12.

17. M.M. Kaplan, M.E. Gershwin. Primary biliary cirrhosis. N. Engl. J. Med. 353 (2005) 1261-73.

18. D.E. Jones. Pathogenesis of primary biliary cirrhosis. Gut 56 (2007) 1615-24.

19. P. Yi, M.D. Driscoll, J. Huang, S. Bhagat, R. Hilf, R.A. Bambara, M. Muyan. The effects of estrogenresponsive element- and ligand-induced structural changes on the recruitment of cofactors and transcriptional responses by ER alpha and ER beta. Mol. Endocrinol. 16 (2002) 674-93.

20. D. Alvaro, P. Invernizzi, P. Onori, A. Franchitto, A. De Santis, A. Crosignani, R. Sferra, S. GinanniCorradini, M.G. Mancino, M. Maggioni, A.F. Attili, M. Podda, E. Gaudio, E. Estrogen receptors in cholangiocytes and the progression of primary biliary cirrhosis. J. Hepatol. 41 (2004) 905-12.

21. D. Alvaro, M.G. Mancino, P. Onori, A. Franchitto, G. Alpini, H. Francis, S. Glaser, E. Gaudio, E. Estrogens and the pathophysiology of the biliary tree. World J. Gastroenterol. 12 (2006) 3537-45. 